\title{
KARAKTER TOKOH FAHRI DALAM NOVEL AYAT-AYAT CINTA KARYA HABIBURRAHMAN EL SHIRAZY: KAJIAN PSIKOLOGI INDIVIDUAL ALFRED ADLER
}

\author{
Aprizal Maulani ${ }^{1}$, Rusdiawan ${ }^{2,}$ Ida Bagus Kade Gunayasa ${ }^{3}$ \\ Magister Pendidikan Bahasa Indonesia, Universitas Mataram \\ Email: aprizalmaulani91@gmail.com
}

\begin{abstract}
ABSTRAK
Penelitian ini bertujuan untuk mengetahui bentuk kepribadian tokoh utama yaitu Fahri dalam novel Ayat-Ayat Cinta karya Habiburrahman El Shirazy. Penelitian ini menggunakan metode deskriptif kualitatif dengan teknik analisis isi. Psikologi individual Alfred Adler digunakan sebagai teori untuk menemukan bentuk kepribadian tokoh Fahri dalam novel Ayat-Ayat Cinta. Hasil penelitian menunjukkan adanya enam prinsip pada karakter tokoh Fahri yang berkaitan dengan psikologi individual Adler, diantaranya. Prinsip rendah diri, prinsip superior, prinsip gaya hidup, prinsip diri kreatif, prinsip tujuan semu, prinsip gaya hidup dan prinsip minat sosial. Perubahan psikologi yang terdapat pada tokoh utama Fahri sejak ia menjadi seorang mahasiswa sehingga menjadi orang yang sukses tidak hanya dalam bidang akademik melainkan dalam bidang bisnis yang ia jalankan. Proses yang ia lewati tidak mudah. Ketika merasa menjadi orang yang tidak percaya diri dengan keadaan yang ia rasakan karena tidak pantas menikahi Aisha seorang gadis dari keturunan terpandang. Rasa berkecamauk ketika ia harus menduakan Aisha dengan menikahi Maria. Perjuangannya menuju kesempurnaan dengan rintangan tidak sedikit mampu ia lalui dengan gaya hidup dan diri yang kreatif. Tingginya minat sosial yang dimiliki tokoh utama juga menjadi prinsip yang dominan dalam novel ini. Kepeduliannya terhadap orang-orang di sekitarnya, dengan rasa simpati dan empati yang begitu kuat di dalam dirinya ia mampu menyelamatkan tetangganya dan mewujudkan cita-citanya.
\end{abstract}

Kata kunci: karakter, tokoh utama, novel, psikologi, individual.

\section{A. PENDAhUluan}

Terciptanya sebuah karya sastra merupakan hasil imajinatif kreatif pengarang. Di dalam dunia imajinatif pengarang sepenuhnya berkuasa membicarakan, mengupas bahkan memutar balikkan kehidupan manusia. Namun seorang pengarang yang baik akan dapat menampilkan pengalaman hidup manusia berdasarkan situasi dan kondisi yang berlangsung di tengah masyarakat. Karya sastra berusaha menggambarkan kehidupan manusia, tidak 
hanya dalam hubungan dengan manusia lain, tetapi juga hubungannya dengan dirinya sendiri melalui hubungan peristiwa batin. Salah satu bentuk karya sastra yang menarik untuk dikaji adalah novel. Pengkajian terhadap salah satu genre sastra tersebut dimaksudkan selain untuk mengungkapkan nilai estetis dari jalinan keterkaitan antarunsur pembangunan karya sastra tersebut juga diharapkan dapat mengambil nilai-nilai amanat berupa nilai pendidikan di dalamnya. Nilai-nilai amanat yang terdapat dalam novel merupakan nilai-nilai universal yang berlaku bagi masyarakat seperti nilai moral, etika, dan religi. Nilai-nilai amanat itu tercermin dalam tokoh cerita, baik melalui deskripsi pikiran, maupun perilaku tokoh.

Ayat-Ayat Cinta yang menceritakan kehidupan tokoh utama seorang pemuda yang bernama Fahri sebagai mahasiswa asal Indonesia yang akan menyelesaikan gelar magisternya di Universitas Al-Azhar Mesir. Ia tinggal di apartemen bersama mahasiswa asal Indonesia lainnya. Dalam kehidupan sehari-hari Fahri selalu berusaha untuk memberikan teladan yang baik bagi teman-temannya. Hal itu tercermin dari perilakunya di apartemen yang selalu mengingatkan kebaikan kepada teman-temannya dan saling tolong menolong. Ia bertahan hidup dengan menjadi penerjemah buku-buku agama, dia adalah laki-laki yang hampir sempurna, tidak mengenal cinta sebelum menikah. Banyak hal yang menjadi pertimbangan tokoh utama Fahri untuk memutuskan menikah. Menyadari dirinya dari keluarga tak berada membuat rasa kurang percaya diri dalam dirinya, dia berpikir ke depannya bagaimana cara menghidupi pasangannya dengan pendapatan yang sangat paspasan. Namun ketika menerima perjodohan dari salah seorang gurunya membuatnya menjadi berubah pikiran awalnya pesimis kini ia menjadi optimis, dengan menikah ia menjadi lebih termotivasi untuk mengerjakan tesisnya. Lewat perjodohan dari salah seorang gurunya ia menikahi Aisha, gadis Mesir keturunan orang terpandang. Aisha menerima segala kekurangan yang ada dalam diri Fahri.

Kehidupan Fahri banyak berubah setelah menikah dengan Aisha, ia harus mengikuti gaya hidup istrinya yang tidak pernah kekurangan dari segi materi. Fahri mampu mengimbangi kehidupan istrinya, ia selalu berusaha membuat istrinya bahagia. Hari-hari bahagia mereka lewati tidak begitu lama, Fahri mendapat musibah dengan tuduhan fitnah yang tidak pernah ia duga sebelumnya. Noura gadis Mesir yang ia tolong dulu kini jadi 
bomerang bagi hidupnya, ia menuduh Fahri telah menghamilinya. Fahri ditangkap atas kasus tersebut. Ia mulai pasrah dengan hidupnya. Siksaan demi siksaan ia rasakan di dalam penjara. Kondisi itu semakin membuat Aisha sedih, melihat suaminya tak berdaya atas fitnah yang tidak pernah ia lakukan. Masalah lain pun juga muncul secara bersamaan, saat di dalam penjara Fahri mendapat kabar bahwa Maria gadis yang selama ini banyak membantunya berada di rumah sakit. Ia koma beberapa hari dan hanya Fahri yang dapat menyembuhkannya. Ia harus menikahi Maria, karena itu jalan satu-satunya. Kondisi psikologinya semakin down. Menikahi Maria berarti akan menyakiti Aisha dan itu adalah keputusan yang tidak mudah baginya. Namun disatu sisi ia juga harus menyelamatkan Maria.

Tidak sampai di sana saja, Habiburrahman El Shyrazi menghadirkan kembali tokoh Fahri dalam Ayat-Ayat Cinta 2 dengan kehidupan yang semakin kompleks. Fahri menjadi salah seorang dosen di University of Edinburgh. Masalah yang dihadapi Fahri tidak hanya tentang isu islamophobia, namun sejak awal kepindahannya ke Edinburgh masalah yang selalu menghantuinya adalah ketidakjelasan tentang nasib istrinya yaitu Aisha. Kepergian Aisha bersama salah seorang sahabatnya ke Palestina meninggalkan luka mendalam bagi Fahri,informasi terakhir yang didapatkan justru mengabarkan bahwa istrinya tewas akibat serangan tentara Israel. Hari-hari yang dilewati tidak berjalan mulus seperti ia menjalani bisnisnya di sana, kehadiran orang-orang di sekitarnya seolah menjadi duri yang setiap saat bisa melukai bahkan membunuhnya. Keira tetangga rumahnya di Stoneyhill Grove yang sangat membenci Fahri selalu mengancam kehidupanya karena keislamannya. Brenda perempuan pemabuk selalu merepotkan Fahri dengan ketidaksadarannya yang sering tidur di depan rumah Fahri dan Baruch cucu nenek Catarina yang menjadi lawan tangguh Fahri karena ia tahu bahwa Fahri ikut campur dalam masalah keluarganya.

Dalam penelitian ini penulis akan menjawab pertanyaan bagaimanakah karakter tokoh utama Fahri menggunakan teori psikologi individual Alfred Adler? Seperti apakah enam prinsipyang ada dalam tokoh Fahri terkait dengan psikologi individual Adler.

\section{B. KAJIAN TEORI}

Menurut Suryabrata (2016:191) psikologi individual mempunya arti penting sebagai cara untuk memahami tingkah laku manusia. Psikologi individual dikembangkan oleh 
Alfred Adler, sebagai sebuah sistem yang komparatif dalam memahami individu dan dalam kaitannya dengan lingkungan sosial. Psikologi individual dikembangkan oleh Adler dan pengikutnya antara lain adalah Rudolph Drekurs, Martin Son Tesgard, dan Donal Dinkmeyer. Alfred Adler lahir di Wina pada tahun 1870, Dia menyelesaikan studinya dalam lapangan kedokteran pada Universitas Wina pada tahun 1895.

Sejak tahun 1935 Adler menetap di Amerika Serikat. Di sana dia melanjutkan prakteknya sebagai ahli penyakit syaraf dan juga menjadi guru besar dalam psikologi medis di Long Island College of Medicine. Dia meninggal di Scotlandia pada tahun 1937, ketika sedang dalam perjalanan keliling untuk memberikan ceramah-ceramah. Seperti Psikoanalisis pengaruh Adler juga lekas meluas, walaupun tidak seluas pengaruh Psikoanalisis.

Alwisol (2014:64) mengungkapkan bahwa teori Adler pada dasarnya sederhana dan ringkas. Bagi Adler, manusia itu lahir dalam keadaan tubuh yang lemah, tak berdaya. Kondisi ketidak berdayaan itu meni,bulkan perasaan inferiorita dan ketergantungan kepada orang lain. Psikologi individual memandang individu sebagai mahluk yang saling tergantung secara sosial. Demikian juga yang diungkapkan oleh Natawidjaja (1987:129) bahwa teori Adler lebih banyak memperhatikan faktor sosial dari perilaku manusia daripada aspek biologisnya, termasuk hal-hal yang berkenaan dengan pengarahan tujuannya. Karena menurutnya bahwa perjuangan yang paling penting dari manusia adalah perjuangan untuk mencapai keberartian, yang merupakan gerakan ke arah pemenuhan tujuan untuk mencapai identitas yang unik dan untuk memiliki sesuatu. Pendekatan "sebabsebab historis" dari Freud memandang perilaku manusia itu dikuasai oleh kekuatan yang ada di dalam dirinya dan di luar daya kendali orang yang bersangkutan. Sebaliknya, Adler menekankan penentuan diri dan kesadaran (bukan ketidaksadaran) sebagai pusat kepribadian manusia. Manusia bukan korban nasib melainkan merupakan mahluk kreatif, aktif dan selalu membuat pilihan, yang setiap tindakannya mempunyai tujuan dan mempunyai arti. Pendekatan Adler juga menekankan tanggung jawab, perjuangan mencapai kelebihan dari orang lain, dan upaya mencari nilai-nilai dan keberartian hidup.

Adapun Pokok-pokok teori Adler yang diungkapkan oleh Suryabrata (2016:185) antara lain. 


\section{Prinsip Rasa Rendah Diri (Inferiority Principle)}

Adler mengungkapkan (dalam Feist 2010:83) bahwa semua manusia "dikaruniai" tubuh yang kecil, lemah, dan inferior saat lahir. Kelemahan ini memicu perasaan inferior hanya karena manusia memiliki kecendrungan bawaan untuk meraih sesuatu yang utuh atau lengkap. Sebenarnya sejak lahir manusia sudah membawa daya juang dalam dirinya.Sifat dan daya juang tersebut ditentukan oleh perasaan inferior.Daya juang harus dikembangkan dan setiap individu mempunyai caranya sendiri dalam mengembangkan daya juangnya. Pada saat idnividu mencapai usia empat atau lima tahun, individu memulai dengan menetapkan sebuah arah bagi daya juang dan membuat sebuah tujuan. Tujuan tersebut mmemberikan panduan untuk memotivasi membentuk perkembangan psikologis dan memberikannya target.

\section{Prinsip Superior (Superiority Principle)}

Alwisol (2014:64) menjelaskan bahwa pada awal pengembangan teorinya, Adler menunjuk agresi sebagai kekuatan dinamik dalm diri yang melatar belakangi semua motivasi, kemudian menjadi konsep "perjuangan menjadi superior." Istilah tersebut Ia kenalkan untuk orang yang sehat yang berjuang mencapai kesempurnaan bagi semua orang, perjuangan yang dimotivasi oleh minat sosial yang sudah berkembang. Perjuangan bisa jadi mempunyai motivasi yang berbeda, tetapi semuanya diarahkan menuju tujuan final. Ia juga menjelaskan bahwa perjuangan menjadi superior yang dilatar belakangi oleh motivasi sosial disebut perjuangan menjadi sukses. Orang yang secara psikologi sehat, mampu meninggalkan perjuangan menguntungkan diri menjadi perjuangan yang dimotivasi oleh minat sosial, perjuangan untuk menyukseskan nilainilai kemanusiaan. Hal yang senada juga diungkapkan oleh Feist (2010:84) bahwa manusia berjuang meraih superioritas atau keberhasilan sebagai cara untuk mengganti perasaan inferior atau lemah. Setiap manusia mempunyai konsep keberhasilan dan definisi keberhasilan masing-masing.

\section{Prinsip Gaya Hidup (Style of Life Principle)}

Adler (dalam Natawidjaja 1987:136) memandang manusia itu sebagai perilaku, pencipta dan seniman dalam kehidupannya. Dalam berusaha mencapai tujuan-tujuan yang berarti baginya, setiap manusia mengembangkan gaya hidup yang unik. Konsep ini 
menjelaskan bagaimana perilaku manusia itu tetap bersatu, sehingga terdapat keajegan pada setiap tindakannya.Apapun yang dilakukan manusia selalu berkaitan dengan tujuan akhir dari hidup manusia yang bersangkutan.

\section{Prinsip Diri Kreatif (Creative Self Principle)}

Adler (dalam Suryabrata 2016:191) Diri yang kreatif adalah faktor yang sangat penting dalam kepribadian individu, sebab hal ini dipandang sebagai penggerak utama bagi semua tingkah laku.Dengan prinsip ini Adler ingin menjelaskan bahwa manusia adalah seniman bagi dirinya.Ia lebih dari sekedar produk lingkungan atau mahluk yang memiliki pembawaan khusus. Individu menafsirkan kesan yang diterima dari lingkungan kehidupannya, mencari pengalaman yang baru untuk memenuhi keinginan untuk superior supaya tercipta diri yang berbeda dari orang lain, yang mempunyai gaya hidup sendiri.

Adler juga menjelaskan (dalam Feist 2010:92) Ia percaya bahwa setiap orang memiliki kebebasan untuk menciptakan gaya hidupnya sendiri. Pada akhirnya, setiap orang bertanggung jawab akan dirinya sendiri dan bagaimana mereka berperilaku. Daya kreatif yang mereka miliki membuat mereka mengendalikan kehidupannya sendiri, bertanggung jawab akan tujuan akhir mereka, menentukan cara yang mereka pakai untuk meraih tujuan akhir mereka, dan berperan dalam membentuk minat sosial. Daya kreatif membuat setiap orang menjadi individu bebas.

\section{Prinsip Tujuan Semu (Fictional Goals Principle)}

Feist (2010: 82) menjelaskan bahwa setiap orang mempunyai kekuatan untuk menciptakan sebuah tujuan fiksional sesuai pribadinya yang dibuat dari bahan-bahan mentah yang disediakan oleh faktor keturunan dan lingkungan. Akan tetapi, tujuan tersebut tidak ditentukan secara genetis atau lingkungan, melainkan lebih sebagai produk daya kreatif, yaitu kemampuan manusia untuk secara bebas membentuk perilakunya dan menciptakan kepribadian mereka sendiri.Dengan kata lain, tujuan yang dirumuskan individu adalah semu karena dibuat amat ideal untuk diperjuangkan sehingga mungkin saja tidak dapat direalisasikan.

Adler (dalam Alwisol 2014:65) juga menjelaskan bahwa tingkah laku ditentukan oleh persepsi harapan yang mungkin dicapai di masa datang, bukan oleh apa yang 
dikerjakan di masa lalu. Ia juga menjelaskan bahwa manusia hidup dengan berbagai macam pikiran dan cita-cita yang semata-semata bersifat fiktif, tidak ada dalam kenyataan. Misalnya pandangana bahwa "kalau ada kemauan pasti ada jalan". Itu bersifat fiktif, idealism yang membuat orang tidak putus asa. Oleh karena itu tujuan fiksional atau semu ini tak dapat dipisahkan dari gaya hidup dan diri kreatif. Manusia bergerak ke arah superioritas melalui gaya hidup dan diri kreatifnya. Tujuan semu yang dimaksudkan ialah pelaksanaan kekuatan-kekuatan tingkah laku manusia. Melalui diri keratifnya manusia dapat membuat tujuan semu dari kemampuan yang nyata ada dan pengalaman pribadinya.

6. Prinsip Minat Sosial (Social Interest Principle)

Feist (2010:88) mengungkapkan bahwa minat sosial adalah perasaan menjadi satu dengan umat manusia yang secara tidak langsung keanggotaan dalam komunitas sosial seluruh manusia. Minat sosial juga didefinisikan sebagai sikap keterkaitan dengan umat manusia secara umum maupun sebagai empati untuk setiap anggota masyarakat. Minat sosial terwujudkan dalam bentuk kerja sama dengan orang lain untuk kemajuan sosial bukan untuk kemajuan pribadi. Inferioritas alamiah dari manusia menyebabkan mereka mengikatkan diri bersama-sama untuk membentuk masyarakat. Adler menyatakan bahwa manusia memiliki minat sosial. Manusia dilahirkan dikaruniai minat sosial yang bersifat universal. Kebutuhan ini terwujud dalam komunikasi dengan orang

lain, yang pada masa bayi mulai berkembang melalui komunikasi anak dengan orang tua. Proses sosialisasi membutuhkan waktu banyak dan usaha yang berkelanjutan. Individu diarahkan untuk memelihara dan memperkuat perasaan minat sosialnya ini dan meningkatkan kepedulian pada orang lain. Melalui empati, individu dapat belajar apa yang dirasakan orang lain sebagai kelemahannya dan mencoba memberi bantuan kepadanya.

\section{METODE PENELITIAN}

Metode yang digunakan dalam penelitian ini adalah metode kualitatif deskriptif. Menurut Moleong (2002: 6) dalam analisis deskriptif, data yang dikumpulkan berupa katakata, gambar dan bukan angka-angka. Objek penelitian yang dianalisis adalah karakter 
tokoh Fahri dalam novel Ayat-Ayat Cinta karya Habiburrahmah El Shirazy. Data penelitian berupa kata, frasa, klausa, dan kalimat yang terdapat dalam novel Ayat-Ayat Cinta karya Habiburrahmah El Shirazy. Teknik pengumpulan data menggunakan metode pustaka, simak, dan catat. Teknik pustaka yakni mempergunakan sumber-sumber tertulis untuk memperoleh data (Subroto,1992, 24).Teknik analisis data menggunakan teknikanalisis isi, yaitu dengan menguraikan dan menganalisis serta memberikan pemahaman atas teks-teks yang dideskripsikan.

\section{HASIL DAN PEMBAHASAN}

Berdasarkan pemaparan sebelumnya, masalah yang akan dibahas di sini adalah karakter tokoh utama Fahri dengan psikologi individual Adler. Berikut gambaran tentang karakter tokoh Fahri dalam novel Ayat-Ayat Cinta karya Habiburrahman El Shirazy.

\section{Prinsip Rendah Diri}

Prinsip rasa rendah diri tokoh Fahri dimulai saat ia menyadari dirinya merasa kurang sempurna terhadap apa yang ia miliki. Ia tidak mampu memahami karakter Maria yang merupakan tokoh nonmuslim tapi mampu menghafal beberapa surat dalam Al-Qur'an namun ia tidak mau memeluk islam. Rasa rendah diri digambarkan oleh tokoh Fahri ketika ia merasa jadi manusia “lemah' yang masih banyak kekurangan untuk memahami rahasia Tuhan di dunia ini. Selanjutnya rasa rendah diri yang digambarkan tokoh Fahri adalah ketika ia kurang percaya diri untuk menikahi Aisha. Ada beberapa faktor yang menyebabkan meras tidak pantas untuk menikahi gadis keturunan Jerman tersebut. Diantaranya, dia belum mempunya penghasilan yang tetap untuk menafkahi calon istrinya kelak karena penghasilan yang ia dapatkan hanya dari hasil menerjemah yang hanya untuk mencukupi kebutuhannya sendiri setiap bulan. Selain itu faktor yang menyebabkannya merasa kurang percaya diri adalah dari garis keturunan. Aisha yang merupakan keturunan orang terpandang dan dari keluarga berada dibandingkan dengan dirinya hanya seorang mahasiswa yang berbekal beasiswa dari keturunan orang yang tidak berada. Selain itu prinsip rasa rendah diri yang digambarkan oleh tokoh utama yakni ketika ia merasa fisiknya tidak sempurna. Saat ia di dalam penjara karena kasus dirinya yang difitnah tanpa bukti. 
Ketika berada di dalam penjara fisiknya disiksa dan perlakuan keji terhadap kemaluannya. Ketidakberdayaannya saat melawan Baruch preman yang ia temui di saebuah tempat hiburan malam. Saat itu ketika mengikuti Sabina dan bermaksud menolongnya dari pelecehan yang dilakukan oleh Baruch dan teman-temannya.

\section{Prinsip Superior}

Prinsip superior tokoh Fahri merupakan prinsip dasar untuk melakukan perubahanperubahan pada dirinya. Perjuangannya untuk mencapai kesempurnaan dan keberhasilan dari segala upaya yang ia lakukan demi dirinya dan keluarganya. Perjuangan tersebut didorong oleh tekadnya yang ingin membanggakan kedua orang tuanya dan orang-orang di sekitarnya. Sifat rajin, konsisten, kerja keras dan menyukai tantangan, ini ditunjukkan pada gambaran karakter tokoh Fahri ketika ia konsisten menghadiri thallaqi yang tujuannya untuk mengembangkan kemampuan membaca dan menafsirkan Al-Qur'an. Ia melawan sengatan panas matahari dan angin kencang demi memenuhi janji pada dirinya untuk menjadi orang yang berhasil dan memenuhi amanat dari kedua orang tuanya. Tidak hanya itu sifat rajin konsisten yang digambarkan oleh tokoh Fahri ketika ia selalu pergi shalat berjamaah di masjid biasa tempat ia mengadu segala keluh kesah tentang hidupnya. Masjid tempat ia merancang segala strategi dan perjuangan panjang untuk ia mencapai kesempurnaan tidak hanya di dunia melainkan juga di akhirat. Bagaimana caranya agar mampu bertahan hidup di daerah rantuan dengan menyelesaikan studinya sesuai dengan waktu yang telah ia rencanakan. Perjuangan menuju superior dengan meninggalkan rasa rendah dirinya juga digambarkan tokoh Fahri ketika ia mau menikahi Aisha dengan segala kekurangan yang ia miliki khususnya dibidang materi dan dengan segala perjuangannya ia mampu membahagiakan istrinya dan menjadi suami yang sempurna untuk istrinya. Perjuangan superior juga ditunjukkan pada sifat tokoh utama yang menyukai tantangan. Saat itu tokoh fahri ditugaskan untuk menggantikan salah seorang dosen untuk mengisi perkuliahan, dengan kepercayaan diri dan kemampuan yang ia miliki ia mampu menjadi seorang dosen yang digemari dan dan diperhitungkan keberadaannya. Tidak sampai di situ perjuangan menuju superior digambarkan juga ketika tokoh utama mampu menghilangkang ketidakpercayaan dirinya untuk bermain biola. Saat itu ia dan teman-temannya menggalang 
aksi untk penggalangan dana dengan cara member pertunjukan seni kepada masyarakat untuk membantu saudara-saudara yang di Palestina. Perjuangan superior dengan meninggalkan rasa rendah diri juga digambarkan oleh tokoh Fahri ketika ia mau menikahi Hulya karena keberadaan istrinya yaitu Aisha sampai saat itu belum juga ada kepastian. Dengan kemantapan hati ia mau menikah lagi untuk mencapai kesempurnaan dalam dirinya untuk menghadirkan generasi dan keturunan dari darah dagingnya.

\section{Prinsip Gaya Hidup}

Gaya hidup tokoh utama Fahri yang menjadi seseorang yang tidak mudah menyerah dan percaya pada dirinya sendiri. Semangat pantang menyerah yang ada dalam diri Fahri mampu membawanya menjadi seseorang yang sukses, meraih apa yang menjadi citacitanya. Dorongan dari dalam diri tokoh utama terlihat ketika ia selalu tekun untuk belajar dan mengembangkan dirinya dengan kegiatan-kegiatan yang bermanfaat untuk menunjang ilmu pengetahuannya. Ketika ia mampu melewati cuaca yang sangat ekstrim perjalanan dari flat menuju tempat talaqqi. Kadang ia tidak memperdulikan kesehatannya demi memenuhi janji untuk datang tepat pada waktunya. Dorongan dari dalam diri tokoh utama juga terlihat dari bagaimana caranya untuk memperoleh penghasilan untuk membiayai kehidupannya sehari-hari. Selain sibuk talaqqi ia juga harus memikirkan bagaimana caranya mengatur waktu untuk menerjemah. Profesinya sebagai penerjemah pernah dipandang sebelah mata oleh temannya, namun ia tidak tidak memperdulikan anggapan orang lain. Dorongan dari dalam dirinyalah yang mampu membuatnya tetap bertahan. Setelah mencapai kesuksesan lantas ia tidak begitu saja berpangku tangan dengan apa yang ia miliki saat itu. Ia tetap bersemangat untuk selalu mengembangkan keilmuan yang dimiliki, setelah menjadi sseorang dosen di University of Edinburgh tidak menghentikan langkahnya untuk terus mencapai kesempurnaan. Ia memberanikan dirinya menjadi dosen pengganti yang telah diamanatkan kepadanya., awalnya dia ragu untuk mengajar mahasiswa di universitas tersebut. 


\section{Prinsip Diri Kreatif}

Diri kreatif yang dilakukan tokoh utama dalam mengembangkan pengalamannya untuk memenuhi tujuannya. Fahri mampu memakai pengalaman yang ada dalam dirinya ketika terjadi keributan di dalam metro. Saat itu ia mampu menurunkan amarah orang Mesir dengan menyuruh mereka untuk bershalawat. Keributan yang terjadi saat itu bermula ketika ada orang Amerika menjadi penumpang di metro tersebut, namun dalam pandangan orang Mesir kalau orang Amerika adalah orang-orang nonmuslim yang banyak membuat masalah dan memandang orang-orang muslim sebagai teroris. Saat itu orang Amerika yang berada dalam penumpang tersebut mengenakan pakaian yang sangat tidak wajar menurut mereka, memakai celana pendek hanya menutupi bagian intim, begitupun denganbaju yang mereka kenakan. Orang-orang yang ada di dalam metro tidak menerima keberadaan orang Amerika tersebut sehingga mereka menghina, bahkan ingin mengusirnya, namun keberadaan Fahri membuat suasana tersebut menjadi kondusif, ia tahu bagaimana cara mengatasi amarah orang-orang Mesir tersebut sesuai dengan pengalaman yang pernah ia rasakan juga ketika ia menanyakan cara menurunkan amarah kepada gurunya. Selain menjadi individu yang aktif dalam mengembangkan pengelamannya Fahri juga mampu menentukan cara untuk mencapai superioritas dan tujuan finalnya. Ia mampu membuat planning serta membuat peta hidup yang telah ia rancang untuk beberapa tahun kedepannya. Ia mampu menentukan cara bagaiaman supaya tujuan hidup yang ia telah petakan bisa tercapai tahap demi tahap. Menjadi seorang penerjemah salah satu profesinya untuk mencukupi kebutuhan hidupnya sehari-hari di daerah rantuan. Rutinitasnya yang sangat padat setiap hari hampir membuatnya tidak bisa beristirahat, selain menerjemah ia juga harus mempersiapkan proposal tesis yang akan ia ajukan.

Menerjemah memang bukan profesi yang tidak mudah tetapi bagi Fahri itu menjadi hal

yang tidak terlalu berat karena wawasan dan ilmu pengetahuan yang ia miliki. Ketika ia menerjemah kitab yang sangat berat menurutnya ia harus mengurangi beberapa planning yang pernah ia jadwalkan. Kitab yang ia terjemah adalah Miftah Daris Sa'adahyang membahas masalah ilmu perbintangan, horoskop, pengaruh planet-planet, ramalan nasib dan lain sebagainya. Ia juga mampu menentukan cara ketika ia mendapatkan musibah 
dalam dirinya, terkena penyakit yang selama ini ia tidak pernah duga. Saat itu ia menderita pembekuan darah di dalam kepalanya sehinggan divonis dokter untuk segera dioperasi. Dengan keadaanya seperti itu lantas membuatnya harus merubah beberpa planning yang telah ia rancang. Ia disarankan oleh dokter harus banyak berisitirahat terlebuh dengan cuaca Kairo saat sangat panas, bukan Fahri namanya apabila tidak memanfaatkan waktu sebaikbaiknya. Waktu istirahat yang disarankan dokter ia manfaatkan untuk tetap menerjemah dan mengurangi aktifitas ke luar rumah. Ketika sudah menjadi orang sukses digambarkan dalam cerita Ayat-Ayat Cinta 2 Fahri menjadi tokoh yang konsisten. Ketika ia terus mengembangkan wawasan dan ilmu pengethaun dalam dirinya, tidak hanya dalam bidang akademik. Kesuksesan yang dia raih juga adalah bsinis yang ia pernah kelola bersama istrinya Aisha. Bisnis mereka sangat berkembang mempunyai beberapa cabang di daerah tersebut. Ia pun diminta untuk menjadi pemegang bisnis di beberapa cabang tapi ia harus memilih dan menentukan hal yang lebih penting untuk masa depannya. Ia lebih memilih untuk fokus dibidang akademik. Ia juga mampu memilih hal-hal yang lebih penting yang akan ia lakukan demi masa depannya. Salah satunya ketika ia menolak undangan makan malam dari Tuan Taher dan melanjutkan untuk menulis penelitiannya yang sudah ditunggu oleh Profesor Stevens.

\section{Prinsip Tujuan Semu}

Dalam prinip tujuan semu Fahri membuat tujuan akhir yang akan ia capai selama menjadi mahasiswa S2 di Kairo. Ia tidak ingin mengecewakan keluarganya yang telah memperjuangkannya sehingga bisa melanjutkan studinya. Ia mampu menjadi individu yang disiplin, konsisten dan gigih dalam mencapai masa depan yang ia harapkan. Setelah mampu meyakinkan para dosen dengan judul tesis yang telah ia ajukan, ia harus memikirkan dan merencanakan semua kegiatannya pada hari-hari berikutnya. Kini ia akan disibukkan dengan menulis proposal tesis, tapi disatu sisi ia juga harus menerjemah karena itu merupakan sumber penghasilannya saat ini. Selain itu ia juga tetap untuk menghadiri jadwal talaqqi sebagai salah satu cara untuk mengembangkan diri dan meningkatkan hafalan Al-Qur'annya. Ia kini sudah mulai untuk merencanakan menulis tesis. Ia mulai membeli beberapa buku sebagai bahan yang akan ia gunakan untuk menulis. Sebagai 
individu kreatif yang banyak pengalaman pada suatu waktu ia diminta untuk menjadi narasumber oleh seorang wartawan Amerika yang ingin menggali tentang islam. Ia membuat planning sedemikan rupa agar tidak mengecewakan wartawan tersebut. Ia membuat janji dan mengatur waktu untuk dirinya agar tidak ada yang terlewatkan dari semua agenda yang telah ia rencanakan. Pada hari itu ia harus bertemu dengan wartawan lalu dilanjutkan mengisi khutbah. Sebagai sosok yang bertanggung jawab atas diri dan keluarganya ia tidak mau semua rencana untuk masa depannya satupun tidak berhasil. Citacita dengan tekad yang kuat pada dirinya membuatnya harus bekerja keras mewujudkannya. Salah satu cara unik yang ia lakukan adalah dengan membuat rancangan peta hidup beberapa tahun kedepannya karena menurutnya dengan begitu ia tau sampai sejauh mana usaha yang ia lakukan dan target apa saja yang telah ia raih untuk dirinya.

Menikah adalah salah satu target terbesar dalam dirinya, dalam rancangan hidup yang ia buat selama menulis proposal tesis ia harus menikah supaya ada orang memotivasi dirinya. Satu demi satu target yang ia harapkan dapat terwujud. Menikahi Aisha ketika menulis proposal tesipun mampu ia realisasikan. Kini tujuan hidup yang semulanya ia rancang sendiri harus diatur kembali dengan Aisha. Harapan hidup dan masa depan berdua harus ia rancang demi mewujudkan cita-cita bersama. Kehidupan rumah tangga Fahri ternyata tidak semulus perjalanan akademiknya. Rumah tangga yang telah ia bina dengan Aisha lantas tidak berakhir indah, karena istri yang ia cintai tiba-tiba menghilang setelah ia bersama temannya menggalang aksi kemanusiaan di Palestina. Tujuan hidup yang semula ia rencanakan berdua kini harus kembali ia rencanakan sendiri. Setelah sukses meraih gelar doktornya, tidak cukup sampai di situ kegigihan dan keuletan yang telah ia tanamkan pada dirinya sejak kuliah S2 dulu tidak luntur sampai ia sukses menjadi dosen. Merencanakan untuk dirinya agar hidupnya berguna bagi orang banyak.

\section{Prinsip Minat Sosial}

Tokoh Fahri sebagai individu yang memiliki rasa simpati yang tinggi kepada siapapun, tidak hanya orang yang ia kenal tetapi juga kepada orang asing. Saat ia berkejaran dengan waktu sekali pun tidak bisa melewati suara Maria yang memanggilnya untuk dimintai 
tolong. Maria merupakan gadis nonmuslim sebagai tetangganya saat kuliah dan ia tinggal di apartemen yang sama. Fahri tidak pernah memandang bulu untuk membantu siapapun. Kejadian di dalam metro ketika ia pergi untuk talaqqi juga menjadi bukti bahwa Fahri memang benar-benar sebagai individu dengan rasa simpati yang sangat tinggi. Ia mau berdiri walau dalam kondisi yang sangat lelah, ia lebih memilih mempersilakan orang lain yang lebih berhak untuk duduk di kursi metro yang kosong. Kepedulian ia tunjukkan tidak hanya kepada orang lain, kepada teman-teman satu flat yang merupakan teman seperjuangan dari Indonesia pun lebih ia tonjolkan. Menjadi satu keluarga di daerah rantaun ia tunjukkan dengan menjadi kepala keluarga yang harus mengatur dan membagi segala sesuatunya untuk kepentingan bersama. Tinggal di apartemen dengan banyaknya tetangga tidak pernah membuatnya mengeluh justru keberadaan tetangganya menjadi motivasi tersendiri untuk mencapai tujuan finalnya. Tidak hanya Maria, tetangga yang ia bantu juga adalah Noura, gadis malang yang disiksa oleh orang tuanya hanya karena ia tidak mau menuruti perintah orang tuanya yang menyuruhnya menjadi wanita pekerja malam. Noura lebih memilih disiksa daripada harus menjual kehormatanya pada lelaki hidung belang. Gadis dengan keteguhan hati yang kuat tentang islam. Fahri tergerak untuk membantu Noura, malam itu ketika ia mendengar tangisan Noura yang habis disika oleh ayahnya Fahri mengajak teman-temannya tidak terkecuali ia melibatkan Maria untuk menyelamatkan hidup Noura malam itu. Ia meminta Maria untuk mendekati Noura lalu membawanya ke rumahnya. Masalah tidak berakhir sampai disitu, Maria dan keluarga ternyata takut untuk menyembunyikan Noura terlalu lama di rumahnya, karena lokasi mereka tinggal berdekatan dengan tempat Noura. Fahri tidak kehabisan cara ia meminta bantuan kepada teman-teman mahasiswi yang berada di asrama Indonesia untuk menampung Noura beberapa hari sebelum ia menentukan rencana berikutnya.

Satu persatu tujuan hidup dalam dirinya tercapai, ia menikahi Aisha walau dengan rasa kurang percaya diri. Perbandingan strata sosial membuatnya minder karena ia hanya seorang anak petani yang tinggal di pelosok Indonesia sementara Aisha seorang gadis dari keturunan terpandang dan berada. Keberanianlah yang mampu menggugurkan semua rasa kurang percaya dirinya, hingga tiba menjelang hari $\mathrm{H}$ pernikahannya ia meminta teman- 
temannya untuk membantunya mengurus rangkaian acara pernihakannya. Setelah menikah dengan Aisha kehidupan Fahri hari demi hari mulai berubah. Setelah lulus S2 ia melanjutkan studinya untuk menjadi seorang doctor dan bekerja sebagai dosen di Universitas of Edinburgh. Ia tinggal di Britania Raya, kepedulian terhadap sesama ketika menjadi mahasiswa S2 di Kairo dulu kini ia tunjukkan kembali kepada semua tetanggatetangganya. Tanpa diminta ia membantu beberapa tetangganya yang sedang dalam kesusahan. Keira dan keluarganya yang krisis moral, Brenda wanita kristen yang tinggal sendiri dengan kebiasaan buruknya yang mabuk-mabukan, dan Nenek Catarina wanita tua yang menghabiskan sisa umurnya sendiri tiada seorang pun yang menemaninya. Dengan segala kemampuan yang dimiliki Fahri menolong mereka semua tanpa perhitungan sedikitpun. Membantu Keira untuk mewujudkan cita-citanya, begitu juga dengan adiknya Jason mereka dibantu Fahri tanpa rasa pamrih sedikitpun. Kepedulian Fahri terhadap sesama untuk mencapa supriornya juga ditunjukkan ketika ia membantu Misbah, sahabatnya ketika di Kairo dulu, Fahri menjadi malaikat untuk Misbah, karena pada saat itu Misbah yang hampir putus asa untuk menyelesaikan S3-nya terkendala biaya tetapi pertemuannya dengan Fahri mampu membangkitkan semangatnya kembali. Rasa simpati juga ia tunjukkan kepada Sabina, gadis bercadar dengan suara serak dan muka yang sedikit rusak. Ia membantunya dengan menyuruh Sabina tinggal bersamanya. Sabina seorang warga asing yang tidak memiliki tempat tinggal di daerah tersebut. Fahri tergerak untuk menolongnya bahkan pernah berencana untuk menikahinya. Prinsip minat sosial yang ditunjukkan Fahri juga ia lakukan kepada rekan kerjanya di Universitas of Edinburgh. Kepada keluarga istrinya yang datang berkunjung ke tempatnya demi terwujudnya tujuan akhir dan superioritas untuk dirinya.

\section{E. SIMPULAN}

Berdasarkan pembahasan di atas dapat disimpulkan bahwa Prinsip rendah diri pada tokoh utama Fahri yakni adanya rasa kurang percaya diri ketikah hendak menikah dengan Aisha. Rasa kurang percaya diri tersebut muncul karena mengetahui bahwa Aisha adalah perempuan dari keturunan orang terpandang dan berada dibandingkan dengan dirinya 
hanya laki-laki miskin yang mendapat beasiswa untuk melanjutkan studinya di Kairo dan mengandalkan hasil terjemahannya untuk mencukupi kebutuhan hidupnya sehari-hari. Selain menikahi Aisha rasa kurang percaya diri juga timbul pada Fahri yang diceritakan pada novel kedua, ia hendak disuruh untuk menikah lagi dan akan dijodohkan oleh cucu Syaikh Utsman yang merupakan guru talaqqinya saat di Kairo dulu. Salah satu alasan kenapa ia tidak bisa menikahi cucu dari gurunya itu ia tidak mendzaliminya. Menikahinya berarti akan menyakiti hatinya karena rasa cinta Fahri pada Aisha saat itu masih tidak bisa digantikan. Prinsip yang kedua adalah perinsip superior.

Tokoh utama Fahri mampu meninggalkan rasa rendah dirinya dan memotivasi diri untuk bisa mencapai kesempurnaan dalam hidupnya. Ketidak percayaan dirinya untuk menikahi Aisha mampu ia taklukan, ia memberanikan diri untuk menerima tawaran perjodohan yang dilakukan oleh Syaikh Akhmad. Ia memantapkan hatinya untuk menikahi Aisha ia mampu meninggalkan perbedaan-perbedaan dirinya dengan Aisha terkait dengan starata sosial. Selain menikahi Aisha tokoh Fahri juga merupakan tokoh yang sangat giat dan memacu dirinya untuk mencapai tujuan masa depan yang selama ini ia dambakan. Semua yang dicita-citakannya tercapai, setelah menikahi Aisha dan lulus S2 di Kairo kesuksesan Fahri semakin berkembang tidak hanya dalam bidang akademik melainkan juga dalam bidang bisnis yang selama ini telah ia rintis bersama istrinya.

Prnsip yang ketiga adalah prinsip gaya hidup, dorongan dari dalam diri Fahri mampu mebuatnya mencapai superioritas. Keuletan dan disiplin dalam hidup menjadi penggerak utama daalm dirinya untuk selalu melakukan hal-hal yang berkaitan dengan pengembangan dirinya. Ia tidak pernah mengeluh dengan segala tantangan yang diahadapi ketika hendak melakukan kegiatan-kegiatan di luar dari bagian kuliahnya. Dorongan dari 
dalam dirinya mampu mengalahkan segala kemalasan dan rintangan yang akan membuatnya gagal. Ia adalah individu yang mampu mengembangkan dirinya demia mencapai tujuan akhir yang telah ia rancang. Prinsip yang keempat terkait teori psikologi individual Adler adalah prinsip diri kreatif. Ia menjadi individu yang aktif dalam memakai pengalaman dalam dirinya, terbukti ketika ia bisa menurunkan amarah dan melerai pertikain yang terjadi di dalam metro. Dengan pengalaman yang sudah tidak diragukan lagi tentang akidah islam ia juga mampu melerai keributan yang terjadi di sebuah masjid ketika para jamaah hendak mengusir dan mengumpat seorang pengemis bercadar di halaman masjid tersebut. Terakhir adalah prinsip minat sosial. rasa simpati dan empati yang sangat tinggi terhadap sesama sehingga ia tidak memperdulikan keselamatan untuk dirinya sejak tinggal di apartemen sewaktu menjadi mahasiswa S2 Fahri tidak pernah memandang siapapun dan melihat waktu untuk menolong atau membantu sesama. Apakah ia mengenal atau tidak orang tersebut ia tidak pernah memikirkannya, karena yang terpenting untuk dirinya adalah bagaimana caranya berguna untuk orang lain. Ia tidak pernah memikirkan materi yang akan ia habiskan, ia juga tidak pernah peduli dengan tenaga yang akan ia keluarkan sekalipun nyawa yang menjadi taruhannya. Ketika ia menolong Noura yang disiksa oleh orang tuanya, membantu Nenek

\section{DAFTAR PUSTAKA}

Alwisol. 2009. Psikologi Kepribadian. Malang: UMM Press

Dewi, Eka Olivia. 2015. Kajian Psikologi Individual Alfred Adler Novel Mimpi Anak Pulau Karya Abidah El-Khalieqy Dengan Metode Hermeneutik. NOSI. Volume 3 Tahun 2015.

Feist, Jess dan Gregory J. Feist. 2009. Teori Kepribadian: Theories of Personality I.Jakarta: 
Salemba Humanika.

Moleong, Lexy, 2002. Metodologi Penelitian Kualitatif. Bandung. PT. Remaja Rosdakarya.

Natawidjaja, Rochman. 1987. Pendekatan-Pendekatan Dalam Penyuluhan Kelompok I. Bandung: CV. Diponegoro

Suryabrata, Sumadi. 2008. Psikologi Kepribadian. Jakarta: Raja Grafindo Persada

Subroto.1992. Penelitian Kualitatif. Jakarta: Raja Grafindo Persada. 